Archived version from NCDOCKS Institutional Repository http://libres.uncg.edu/ir/asu/

\title{
Appalacȟ̉n

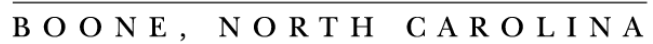

\section{The Armed Forces And The Arab Uprisings: The Case Of Jordan}

\author{
By: Curtis R. Ryan
}

\begin{abstract}
The 2011 uprisings across the Arab world have highlighted the importance of civil-military relations across the region. 1 As uprisings against bleak economic conditions and authoritarian rule spread from Tunisia to Egypt, Libya, Yemen, and Syria, the decisions made by Arab armies and security services have been key to the outcomes in every case.
\end{abstract}

Ryan, C. R. (2012). The Armed Forces and the Arab Uprisings: The Case of Jordan, Middle East Law and Governance, 4(1), 153-167. doi: https://doi.org/10.1163/187633712X626062. Publisher version of record available at: https://brill.com/view/journals/melg/4/1/article-p153_4.xml 


\title{
Essays
}

\section{The Armed Forces and the Arab Uprisings: The Case of Jordan}

\author{
Curtis R. Ryan
}

Appalachian State University

The 2011 uprisings across the Arab world have highlighted the importance of civil-military relations across the region. ${ }^{1}$ As uprisings against bleak economic conditions and authoritarian rule spread from Tunisia to Egypt, Libya, Yemen, and Syria, the decisions made by Arab armies and security services have been key to the outcomes in every case.

In Tunisia, army units in some cases protected protestors against internal police forces. In Egypt, the army deployed units to the center of Cairo itself, but then refrained from firing on the thousands of demonstrators in Tahrir Square, as the top echelon of the officer corps - in the form of the Supreme Council of the Armed Forces (SCAF) - helped push former dictator Husni Mubarak out of office. Yet despite appearing quite similar at face value, the Tunisian and Egyptian cases also seemed to have different trajectories (at least initially), with the first yielding actual regime change and the emergence of a new democracy, and the latter yielding a leadership shift, but not necessarily regime change.

By the end of the tumultuous year 2011, Tunisians had not only ousted their longtime dictator, but had also managed to hold free and fair elections, which in turn led to a carefully negotiated government of left, liberal, and Islamist parties that had previously been illegal. The army, meanwhile, had essentially returned to the barracks. In Egypt, in contrast, the SCAF retained

\footnotetext{
1) In their recent study, Oren Barak and Assaf David make clear how understudied a topic this is. See Oren Barak and Assaf David, "The Arab Security Sector: A New Research Agenda for a Neglected Topic," Armed Forces \& Society 36, no. 5 (2010): 804-824.
} 
power and, despite preparations for parliamentary elections, seemed reluctant to leave or defer any meaningful authority to civilians. Yet for many Egyptians, the army had saved Egypt, had secured the revolution, and had turned out its own leader. But for many democracy activists and demonstrators in Tahrir itself, suspicions of military intentions appeared immediately, and they returned continually to the square, continuing their protests and attempting to hold the army and the SCAF specifically to its promises of reform, democratic elections, and a return to civilian rule. ${ }^{2}$

In short, whether post-Mubarak Egypt would become more democratic or revert to authoritarianism depended in large part on the decisions of the SCAF. These tensions came to a head in November 2011, as police and later army units attacked peaceful demonstrators in Tahrir Square, initially clearing the area through tear gas, beatings, rubber bullets, and eventually live rounds. The deaths of dozens of protesters, however, cowed none of the demonstrators, who returned in ever greater forces, reproducing scenes from the January $25^{\text {th }}$ Revolution itself. Once again, the pivotal issue remained the role of the armed forces, and whether they would step aside and allow an actual transition to civilian rule and to democracy.

In Libya, the regime of Mu'amar al-Qadhafi had chosen to deliberately weaken its own military units, to minimize their potential threat to a state that was itself, after all, a product of a military coup d'etat. Yet as Libyans staged an uprising in the city of Benghazi, many military units defected immediately to the revolutionary forces, while specialized units under direct Qadhafi family control, coupled with foreign mercenaries, turned their weapons on their own population.

Tunisian President Zine al-'Abdin Ben 'Ali fled to exile soon after he found that his military had backed the revolution. Egyptian President Husni Mubarak refused to step down and was arrested and put on trial by the same generals whose loyalty he had cultivated for decades. And Libyan leader Mu'amar al-Qadhafi was eventually toppled by a full-scale uprising, as guerrilla forces of the Transitional National Council (TNC), backed by NATO air strikes, fought city by city, and town by town in their advance across Libya. Qadhafi was eventually captured and killed by guerrilla forces loyal to the TNC. The split in the Libyan armed forces had led not only to revolution, but to a civil war with extensive outside intervention.

Similar intra-military splits emerged in Yemen and Syria, in both cases yielding far more violent outcomes than had occurred in Tunisia and Egypt.

\footnotetext{
2) Author's discussions with leftist and Islamist Tahrir activists in Cairo, Egypt, June 2011.
} 
In Yemen, civil war loomed as units fragmented largely along lines of tribal loyalties as the ruling coalition around President 'Ali 'Abdullah Saleh disintegrated, with armed units following their commanders both for and against the regime. And in predominantly Sunni Muslim Syria, specialized units rooted largely in the ruling 'Alawite minority turned on civilian demonstrators, believing that they were defending their regime - and their minority ruling community - from a post-revolutionary bloodbath. As Syrian government repression dragged on month after violent month, the regime became more isolated globally and regionally, eventually being expelled from the Arab League. Perhaps emboldened by the Bathist regime's increasing isolation, or motivated by its harsh and repressive methods, soldiers began to desert their posts. These desertions, in turn, began to take their toll on the regime's own armed forces, with units of anti-regime deserters - in the form of the Free Syrian Army - re-emerging to engage in pitched battles with their former comrades in arms.

In Bahrain, in contrast, the forces of counter-revolution seemed to have triumphed, as police and army units backed the monarchy against demonstrators calling for reform. Yet loyalty of the security forces in the Bahrain case was apparently not enough, as the Sunni ruling family drew on outside allied forces from Saudi Arabia and the Gulf Cooperation Council (GCC) to secure the regime from its own majority Shi'a population.

In short, in every instance of Arab uprisings, the decisions of soldiers and military officers were critical to the ultimate outcomes; because in every case where the civilian pro-democracy and pro-reform demonstrators were peaceful, the degree of violence was determined not by them, but by the responses and actions of government security forces. And even after regime change, outcomes will depend in large part on the nature of Arab militaries and of civilmilitary relations in each case. ${ }^{3}$

The sheer violence of some of the above cases has meant that the popular demonstrations and demands for change in other states - such as the Hashemite Kingdom of Jordan - have often been overlooked. But Jordan too has been affected by the political winds of the Arab uprisings, leading to demonstrations across the country in solidarity with their counterparts in Tahrir Square and elsewhere, but also with a view to achieving real reform and change within Jordan itself. As civilian demonstrators continued their efforts in weekly protests following Friday prayers, the fortunes of both those in the

\footnotetext{
3) Yezid Sayigh, "Armies and Civilians in the Arab Awakening: An Inevitable Compromise?" Arab Reform Bulletin, November 2011 (Available at: http://carnegie-mec.org/publications/?fa = 45839\&lang $=$ en $)($ accessed November 20, 2011).
} 
streets and in palaces would ultimately turn, at least in part, on the role of the army and security services.

What do civil-military relations imply for reform and change, for regime security, and for democratic opposition in Jordan? In the sections that follow, I will turn first to the demonstrations themselves, then to the regional security dynamic that has yielded such a prominent role for the armed forces in a country that is itself not a military regime. Finally, this analysis will explore how domestic and regional change has impacted the security forces too, and what this may mean for both the regime and democratic opposition in Jordan.

\section{Protests and Reform Demands}

Jordan's demonstrations ranged in make-up from youth-organized protests (which were explicitly non-partisan but pro-reform) to coalitions of opposition parties (usually left wing parties combining forces with the Muslim Brotherhood and the Islamic Action Front Party). Many demonstrations drew on diverse groups, crossing class, gender, ideological, and even ethnic lines; although they seemed to include mostly East Jordanians (rather than Jordanians of Palestinian descent). Since the former community is counted on by the Hashemite monarchy as the bedrock of its support, the demonstrations were clearly worrying and unsettling to the regime, even though they focused mainly on reform demands and not on regime change.

The aims of the protests were fairly consistent - against perceived endemic corruption (associated with the kingdom's extensive economic liberalization and privatization efforts); for increased democratization in the form of meaningful public participation and greater accountability for government officials; and for a shift toward a more constitutional monarchy - with more checks and balances between the executive, legislature, and judiciary. But while months of demonstrations called for restricting monarchical powers, they did not call for the overthrow of the king or of the monarchy more generally.

Yet given the regime changes in nearby Arab states, and the descent into violence in others, the Hashemite regime reacted quickly. The king responded to the 2011 Jordanian demonstrations by sacking the unpopular administration of Prime Minister Samir al-Rifa'i, a mere matter of weeks after reappointing his government. The monarchy then promised a series of reforms and launched a new round of national dialogue committees to re-examine Jordan's laws on elections, political parties, parliamentary life, and even the constitution itself. 
These measures, however, had a familiar feel. As many in Jordan's vast democratic activist movement point out, Jordan has been here before. Contrary to the regional image that the kingdom is actually trailing behind the Arab Spring, in many ways it was at one point far ahead. Jordan's earlier great awakening had occurred in 1989, when harsh economic adjustment measures from an IMF austerity program sent much of the south of Jordan into an uproar. Unrest spread across southern towns previously deemed unquestioningly loyal to then-King Hussein's Hashemite state. Then, as now, protests erupted in Kerak, Tafila, Ma'an, and elsewhere. Then, as now, the protestors called for serious reform, but not regime change. What they got in 1989 was a farreaching process of political liberalization, the lifting of martial law, the legalization of political parties, the loosening of restrictions on the media, and a series of democratic elections for parliament. ${ }^{4}$

After that very promising start, however, the state began to regress in liberalization as it brooked no dissent to its 1994 peace treaty with Israel. ${ }^{5}$ The cost of peace, it seemed, was authoritarian retrenchment. Following the royal succession in 1999 from King Hussein to King Abdullah II, expectations were raised for a liberalization and democratization revival; in effect, for a return to the "Amman Spring" . ${ }^{6}$ And indeed, numerous plans, committees, and slogans have emerged over the years since. But by 2011, stoked once again by severe economic hardship, and with a population now mostly under the age of 30 and seeing worsening job and career opportunities, coupled with rising food and housing prices, Jordanians took to the streets. This time, however, they were especially wary of mere cosmetic change, and called on their regime to either lead or at least follow the reform movement, but in any case not to thwart it.

As protestors had demanded, Rifa'i and his entire cabinet were dismissed. The king then turned back toward the army and security apparatus for support. As he had done after the 2005 al-Qa'ida terrorist bombings in Jordan,

\footnotetext{
4) Rex Brynen, "Economic Crisis and Post-Rentier Democratization in the Arab World," Canadian Journal of Political Science 25, no. 1 (1992): 69-97; Malik Mufti, "Elite Bargains and the Onset of Political Liberalization in Jordan," Comparative Political Studies 32, no. 1 (1999): 100-129; Glenn Robinson, "Defensive Democratization in Jordan," International Journal of Middle East Studies 30, 3 (1998): 387-410.

5) Laurie A. Brand, "The Effects of the Peace Process on Political Liberalization in Jordan," Journal of Palestine Studies 28, no. 4 (1999): 52-67.

6) For a full analysis of the regime transition and its implications, see Curtis R. Ryan, Jordan in Transition: From Hussein to Abdullah (Boulder: Lynne Rienner, 2002).
} 
King Abdullah turned to former general Marouf al-Bakhit as his new prime minister. Bakhit was certainly no democratic reformer, but he was a strong Jordanian nationalist, a member of the influential 'Abbadi tribe, and a former military commander and head of military intelligence. In short, when in crisis, even when the regime turns to civilian support, it seems really to be turning toward the security forces.

\section{Regional Insecurity and Regime Insecurity}

Part of the explanation for the influence of Jordan's security forces lies with the country's difficult political geography. Being wedged between Israel to the west and Iraq to the east has never been a comfortable position for the Hashemite Kingdom of Jordan. The old slogan was that Jordan existed "between Iraq and a hard place." That geostrategic position got worse after 2000 with the collapse of the Middle East peace process, the renewed Palestinian intifadah, and the rise in Israeli-Palestinian violence to the west of the kingdom. And given the large Palestinian presence in Jordan itself (by most accounts more than half the citizens are of Palestinian descent), that is not a small challenge. But after the 2003 U.S. invasion of Iraq, the challenge to Jordanian stability and security grew, and with it, refugee flows grew as well. Hundreds of thousands of Iraqis fled the turmoil and violence of their own country, crossing the border into Jordan and other Arab states.

The presence of the Iraqis, and the general sense that Jordan has been gripped in a vice of turmoil between its eastern and western neighbors has led to a dramatic upsurge in internal political tensions. These revolve mainly around identity issues that are nothing less than existential: in these trying times, who counts as Jordanian? Who can be counted on as a loyal (usually defined as pro-Hashemite) citizen? Conservative East Jordanian nationalists, and the government more generally, are determined to make sure that Iraqis in Jordan do not become the "new Palestinians," to the point that they usually refuse to refer to the Iraqis as refugees at all, but rather as guests. And guests, of course, leave.

Meanwhile, Jordan's neighbor to the south, Saudi Arabia, has been experiencing its own heightened security challenges, leading many in Jordanian government and security circles to worry about the dangers of cross border contagion. Specifically, they have been concerned that Wahhabi elements from the Gulf would strengthen the heretofore minor Salafist trend within 
Jordanian Islamism. ${ }^{7}$ The Salafi movement has historically been a very small part of Jordan's large Islamist movement, which tends to be conservative but democratic and reformist, and based mainly in the Muslim Brotherhood and the Islamic Action Front political party. ${ }^{8}$ Yet Salafis have re-emerged in public activism recently, and Salafi demonstrators did engage in violent clashes with state police and security forces in the city of Zarqa as recently as April 2011.

To the north, Jordan has traditionally had a contentious relationship with Ba'athist Syria, amounting to a regional cold war between the two states for many decades, including extensive (and at times mutual) attempts at subversion. But since 1999-2000, with dynastic successions in both Amman and Damascus, Jordanian-Syrian tensions had decreased substantially, for all intents and purposes ending the longstanding cold war that had existed between President Hafiz al-Asad and King Hussein. ${ }^{9}$ Yet when Syrians first rose to protest the authoritarian regime of Bishar al-Asad, they did so from the Syrian border town of Der'a (just across the border from its Jordanian counterpart, Ramtha). As violent government repression swept across Syria, feeding the flames of rebellion rather than snuffing them out, the Hashemite regime saw turmoil over yet another border.

By 2011, in short, the regional neighborhood seemed even less stable, and even more problematic for the regime than usual. And at no time had it seemed reassuringly "secure." Yet the 2011 Arab uprisings saw a resurgence of popular activism sweep the entire Arab world, as popular movements toppled longstanding authoritarian rulers through revolution, insurgency, or civil war. By 2011, the kingdom had no truly secure border, with security challenges of different types emanating from all directions. And all this impacted an already precarious domestic political context with no shortage of internal problems. Indeed, in his first 12 years in office, King Abdullah II has faced a steadily

\footnotetext{
7) Author Interviews with Jordanian government officials. Amman, Jordan, December 2010 and June 2011.

8) Jillian Schwedler, Faith in Moderation: Islamist Parties in Jordan and Yemen (Cambridge: Cambridge University Press, 2006); Curtis R. Ryan, "Islamist Political Activism in Jordan: Moderation, Militancy, and Democracy," Middle East Review of International Affairs 12, no. 2, (June 2008): 1-13, Quintan Wiktorowicz, The Management of Islamic Activism: Salafis, the Muslim Brotherhood, and State Power in Jordan (Albany: State University of New York Press, 2000).

9) See Curtis R. Ryan, "The Odd Couple: Ending the Jordanian-Syrian 'Cold War'," Middle East Journal 60, no. 1 (2006): 33-56; idem., Inter-Arab Alliances: Regime Security and Jordanian Foreign Policy (Gainesville, FL: University Press of Florida, 2009), 167-183.
} 
rising tide of external and internal challenges to Jordanian stability and to his regime's survival.

\section{The Armed Forces and the State in Hashemite Jordan}

If pro-reform demonstrators in 2011 and 2012 saw parallels to the democratic movement of 1989, many in the state security establishment seemed to have recalled the earlier round of regional regime changes in the 1950's and 1960's. In that earlier round of regime changes, Pan-Arab and left ideological movements swept the Arab world, including regional militaries themselves, and toppled regimes (mainly pro-Western monarchies) in Egypt, Iraq, Syria, Libya, and Yemen. Yet the Jordanian Hashemite monarchy survived, mainly due to its powerful external allies and its main internal pillar of support: the Jordanian armed forces. For the region in general, however, these earlier waves of change led to authoritarian republics with strong bases in the armed forces. But the anti-republican monarchies too came to rely extensively on their armed forces and security services. ${ }^{10}$ In 2011, turmoil and regime change swept many of the same locations as in the 1950's and 1960's, and the Hashemite regime was once again leaning on its army and security services to preserve Jordanian stability and the survival of the monarchy. ${ }^{11}$

Thus while not itself a military regime, the Hashemite monarchy has relied on the armed forces as its main pillar of support since the emergence of the regime itself. Even prior to independence, the first two institutions created in the formation of modern Jordan were the monarchy and the army (then known as the Arab Legion). Originally recruited heavily from among the Bedouin tribes, the army supported the Hashemite rulers and the emerging state, and provided the roots for much of modern Jordanian national identity. ${ }^{12}$

10) Elizabeth Picard, "Arab Military in Politics: From Revolutionary Plot to Authoritarian Regime," in Giacamo Luciani, ed., The Arab State, PAGES (Berkeley: University of California Press, 1990), 189-219.

11) Nicolas Pelham. "Jordan's Balancing Act," Middle East Report Online, February 22, 2011 (www.merip.org) (accessed February 22, 2011)

12) There is a rich literature on the roles of the tribes in forging modern Jordanian national identity, see Yoav Allon, The Making of Jordan: Tribes, Colonialism, and the Modern State (London: I.B. Tauris, 2007); Schirin H. Fathi, Jordan - An Invented Nation? Tribe-State Dynamics and the Formation of National Identity (Hamburg, Germany: Deutches Orient-Institut. 1994); Linda Layne, Home and Homeland: The Dialogics of Tribal and National Identities in Jordan 
Since the country's independence in 1946, Jordan's armed forces have developed a well-deserved reputation for being well-trained and professional, despite their small overall size compared to the armies of their neighbors. ${ }^{13}$ In the early post-independence years, the army retained British officers in command of Arab troops. But in the Pan-Arab nationalist turmoil of the 1950's, pressure increased on the Hashemite monarchy to distance itself from the imperial powers. In 1956, King Hussein surprised his Pan-Arab nationalist and leftist detractors by summarily dismissing the British commander of the Jordanian army, General John Bagot Glubb (better known as Glubb Pasha), after 26 years of service. The Jordanian army was thereafter "Jordanized," shifting all command functions to Jordanian officers. But the ideological currents of the time had nonetheless penetrated the ranks and officer corps of the armed forces, resulting in an attempted coup by a Jordanian version of the "Free Officers" movement. Importantly, the 1958 coup attempt failed due mainly to the loyalty to the monarch of the king's Bedouin troops (who came very close to killing their own traitorous general, Ali Abu Nuwar). ${ }^{14}$

Since demonstrating its Hashemite loyalty in the context of the failed 1958 coup, the armed forces experienced a devastating defeat by Israel in 1967, successfully repelled Israeli forces (which were attacking PLO guerrillas) at Karamah in 1968, and responded to both internal and external challenges to the regime in the civil war of 1970. That last bloody episode is still known as "Black September" to most Palestinians. But to the armed forces, it is seen as a victory for the Jordanian Arab Army over guerrilla forces of the PLO and over Syrian military intervention in northern Jordan. To this day, the violence of September 1970 underscores the army's main two charges: to defend the kingdom against outside attack and to defend the monarchy against internal challenges to Hashemite rule.

(Princeton: Princeton University Press, 1994); and Andrew Shryock, Nationalism and the Geneological Imagination: Oral History and Textual Authority in Tribal Jordan (Berkeley: University of California Press, 1997). On the creation of real and imagined tribal identities and specifically their links to the armed forces and the construction of Jordanian identity, see in particular Joseph A. Massad, Colonial Effects: The Making of National Identity in Jordan (New York: Columbia University Press, 2001), chapters 3 and 4.

13) On the origins and development of the Jordanian armed forces, and its role in political life, see P. J. Vatikiotis, Politics and the Military in Jordan: A Study of the Arab Legion, 1921-1957 (London: Frank Cass, 1967) and Lawrence Tal, Politics, the Military and National Security in Jordan, 1955-1967 (Basingstoke: Palgrave Macmillan, 2002).

14) Arthur Day, East Bank / West Bank: Jordan and the Prospects for Peace (New York: Council on Foreign Relations, 1986), 75-82. 
To that end, the army is technically under civilian control. But it would be more accurate to describe it as under royal control, for the chief of staff of the armed forces reports not to the parliament, prime minister, or defense minister, but directly to the king. ${ }^{15}$ In terms of its overall make-up, today's Jordanian army is no longer the Bedouin-dominated Arab Legion of the 1950's. But given the demographics of the kingdom, including a presumed Palestinian majority among its citizens, the regime ended the practice of conscription in 1992. ${ }^{16}$ This has had clear ethnic effects, as the overwhelming majority of soldiers and officers are of East Bank origin. This also highlights the overall ethnic division of labor in the kingdom, as Palestinian Jordanians tend to dominate the businesses of the private sector, while East Jordanians dominate the public sector: from government civil service, to the police, intelligence services (mukhabarat), and armed forces.

Jordan's highly professionalized army has increasingly globalized its roles, by participating extensively in United Nations Peacekeeping Operations around the world, by providing military field hospitals to natural disaster areas as well as to political crisis areas such as Afghanistan, Iraq, and (after the fall of the Qadhafi regime) Libya. The Jordanian security services have also been very active in providing training for Iraqi police (after the fall of Saddam Hussein's regime) as well as for special forces from around the region. ${ }^{17}$

To emphasize the importance of the armed forces to the state, the annual commemoration of the Hashemite-led "Great Arab Revolt" against the Ottoman Empire is celebrated at the same time as Army Day and Coronation Day. In a sense, these collective holidays are essentially a celebration of patriotism and nationalism, and also of military loyalty to the Hashemite state. King Abdullah II is particularly proud of his own military background. The royal succession in 2000 had been something of a surprise, since Prince Hasan had been slated to succeed King Hussein for more than thirty years. Abdullah had focused instead on a military career and had advanced to become commander of Jordan's Special Forces. Like his father, King Hussein, Abdullah had trained at Sandhurst, the Royal Military Academy in the United Kingdom. But after his surprise career shift to the Hashemite throne itself, in 2000, he

\footnotetext{
15) Nawaf Tell, "Jordanian Security Sector Governance: Between Theory and Practice" (Geneva Centre for the Democratic Control of Armed Forces, Working Paper No. 145, August 2004).

16) In 2007, parliament reintroduced a limited version of conscription, to include merely a few months of service in what amounted to a job-training and national service program.

17) W. Andrew Terrill, Jordanian National Security and the Future of Middle East Stability (Carlisle, PA: Strategic Studies Institute, 2008).
} 
maintained the practice of the Hashemite kings of lavishing the armed forces with arms, materiel, and social support for military families. ${ }^{18}$

Still, in recent years, there have been rumblings of discontent not only in society in general, but also within the army and security services themselves. This was made most vividly clear in the manifesto of retired officers directly criticizing the regime, and essentially accusing it of forgetting its own social bases, of allowing its economic liberalization program to increase corruption, and of selling Jordan - both figuratively and literally - to a new Palestinian technocratic and business elite. ${ }^{19}$ And at least for some hardline nationalists, the very personification of this elite is not outside the regime in the private sector, but within the palace in the form of Queen Rania herself, who is of Palestinian origin. ${ }^{20}$

Political criticism has clearly crossed a line that would have been unthinkable in the days of King Hussein. And these critiques were coming from the regime's own traditional bedrock bases of support. Yet in many ways they mirror the shift in Jordanian society and government itself, as many wealthy Palestinian families see themselves as loyally Jordanian and as the leaders of the king's neoliberal economic development agenda. But as privatization and foreign investment proceed apace, Jordan's traditional social safety nets are gradually disappearing. Thus many rural East Jordanians, with extensive family connections to all the security services, feel increasingly alienated, including even the Bedouin tribes. A prominent member of the Jordanian senate noted this to King Abdullah himself: "I told his majesty the king, they are angry. They are your army. They are your security, You have to do something about it." ${ }^{21}$ Yet despite the stereotypes and ethnic caricatures used by reactionaries against the "other" community within the Kingdom, the increasing class divisions actually cross ethnic divides, with both Palestinians and East Jordanians among the richest and also among the poorest members of society.

\footnotetext{
18) On the Jordanian succession, see Ryan, Jordan in Transition, Ch. 5.

19) Assaf David, "The Revolt of Jordan's Military Veteran's," Foreign Policy, Middle East Channel, June 16, 2010 (http://mideast.foreignpolicy.com/articles/2010/06/15/the_revolt_of_jordans _military_veterans) (accessed June 16, 2010)

20) Laurie Brand, Rym Kaki, and Joshua Stacher, "First Ladies as Focal Points for Discontent," Foreign Policy, Middle East Channel, February 16. Available at: http://mideast.foreignpolicy .com/posts/2011/02/16 (last access: 16/02/2011).

21) Author interview. Amman, Jordan, June 2010.
} 


\section{The Armed Forces, the Regime, and Political Change}

The tensions within the kingdom, in short, seem to be converging - all driven mainly by dramatic economic change - but yielding increased tensions between rich and poor, between West and East Bank Jordanians, between and among Jordanian tribes, and even between civil and military relations. ${ }^{22}$ The king seems to have noticed. In June 2011, King Abdullah used the occasion of Army Day to speak - and to warn - his top army, police, and intelligence officers that disunity would not be tolerated. ${ }^{23}$ But for all the simmering anger and resentment, the Jordanian army is not politicized in the sense of domination by any secular ideological movement or, for that matter, by Islamist sentiments.

It could be that the regime will eventually achieve a much more diverse, pluralistic, and broad support base as these political and economic transitions within Jordan continue. But in the meantime, it is hard to find a constituency that is actually happy with the status quo. The 2011 demonstrations in Jordan were small compared to the whirlwinds that swept Tunisia, Egypt, Libya, Yemen, and Syria, but the regime should not underestimate the level of anger and discontent within the kingdom.

All sides in Jordan called for a return to genuine reform; and most agreed that reform meant greater democratization, less corruption, and an end to merely cosmetic changes in governance. But if the regime continues with its preferred neoliberal policies for economic privatization, it may also have no choice but to enhance the current process of providing welfare and a social safety net via the institution of the armed forces itself. Anne Marie Baylouny has referred to this as "welfare through military employment." ${ }^{24}$ In other words, economic pressures might call for cutting costs and downsizing the security services, but political pressures may lead the regime to maintain the main pillar of regime security by providing more subsidies to the families of those engaged in the civilian and military parts of the public security sector.

\footnotetext{
22) Juan Jose Escobar Stemmann, “Jordan's Future Challenges," Middle East Review of International Affairs 14, no. 4 (December 2010): 47-59.

23) King Abdullah II, "Remarks by His Majesty King Abdullah II on the Occasion of the 11th Anniversary of His Accession to the Throne, The Anniversary of the Great Arab Revolt and Army Day," June 8, 2010 http://www.jordanembassyus.org/new/jib/speeches/hmka/hmka06092010 .htm (Accessed on June, 8, 2010)

24) Anne Marie Baylouny "Militarizing Welfare: Neo-Liberalism and Jordanian Policy," Middle East Journal 62, no. 2 (2008): 277-303.
} 
But even with rising complaints and tensions, the Jordanian army and security services remain solidly pro-Hashemite. They are royalists and equate Jordanian patriotism with Hashemite loyalty. This is so pervasive that it is actually a problem for pro-democracy and pro-reform demonstrators, who often feel the need to go to great lengths to demonstrate that they too are patriotic Jordanians.

There remains, therefore, the danger of the regime and armed forces' overreaction to what are, in fact, entirely legitimate criticisms and demands. Most reformers actually want the king to lead them in this process, and most are aware of the detailed reform agenda that had already been worked out in the form of the "National Agenda" - which was announced in 2005 and then promptly shelved, in part because of resistance from traditionalists and reactionaries in the political elite and security services. ${ }^{25}$ The "National Agenda" is but one of many sets of reform proposals over the years; but the point is that there have been many, and that patience for delays in implementing meaningful change has worn thin across Jordanian society.

\section{Conclusions}

Despite the 2011 uprisings in many countries across the Arab world. reform activism in Jordan had yet to take a revolutionary turn. But the waves of change inherent in the Arab uprisings in 2011 nonetheless affected Jordan as they had all corners of the Arab world. Weekly demonstrations from January 2011 and throughout the year called for political and economic change (in most cases calling for more democratization and at least a partial rollback of economic liberalization, as well as genuine efforts to fight corruption).

In a nationally-televised speech in June 2011 King Abdullah seemed to meet some opposition demands by suggesting that future governments would be drawn from the elected parliament, rather than appointed by the king. National dialogue committees were once again appointed, which called for reforms of laws on parties, elections, parliament, and even the constitution. ${ }^{26}$ What was missing, however, was a clear timetable for implementation, leaving

\footnotetext{
25) Marwan Muasher, The Arab Center: The Promise of Moderation (New Haven: Yale University Press, 2008).

26) Curtis R. Ryan, 'The King's Speech,' Foreign Policy, Middle East Channel, June 17. 2011. Available at: http://mideast.foreignpolicy.com/posts/2011/06/17/the_kings_speech (accessed June 17, 2011)
} 
those for and against reform unclear about how serious the proposals were. Did they amount to still more cosmetic reform or to meaningful change?27 As the "Arab Spring" saw longstanding Arab rulers flee to exile, face arrest and stand trial, or even be shot down by opposition forces, the pressures were intense even on regimes, such as those in Jordan or Morocco, that were not yet facing revolution, but rather calls for reform.

The one thing that seems certain is that the status quo can no longer hold. Old means of holding back opposition - either through coercion or cosmetic reforms - will mollify no one. If some level of political change is inevitable, however, what does this mean for the regime, the military, and reform activists in the Kingdom? There seem to be several possible outcomes. One scenario is that the regime could indeed overly rely on its army and become more of a garrison state in an attempt to hold back change and resist more meaningful public participation in Jordanian political life. Another scenario is that Jordan could return in earnest to the much-heralded democratization process of 1989-1994 and once again become a model for the region. But a third scenario suggests that the regime might take the more typical Hashemite middle ground path, with minor reforms, some level of openness, and simultaneously greater reliance on the army and security services as a kind of hybrid liberalizing and yet still authoritarian regime.

Two of these options may shield Jordan from the kinds of change that have swept the region in the past and in the present. But these short terms strategies cannot work forever. As we have seen throughout the Arab world, the patience of technologically-savvy twenty-somethings for cosmetic change is over. Yet similarly, the patience of old guard members of Jordan's civilian government, army, police, and mukhabarat is also vanishing in the face of the widespread belief that they are losing their country. Most will still fight to defend the Hashemite state; but they insist that the state defend them too. To bridge this gap will require a reassessment not just of governance and institutions, but also of civil-military relations and certainly a more inclusive approach to the identity politics of who is Jordanian, and whom the state is therefore meant to serve. $^{28}$

27) Sean Yom, "Jordan's Fictional Reforms," Foreign Policy, Middle East Channel, November 9, 2011 (http://mideast.foreignpolicy.com/posts/2011/11/09/jordans_fictional_reforms) (accessed November 9, 2011)

28) Some disaffected royalists even seem to prefer Prince Hamza as a future monarch. Hamza (the son of King Hussein and Queen Noor) happens to bear a striking resemblance to his father. On resurgent identity politics, see Curtis R. Ryan, "We are all Jordan ... But who is 'We'?" 
Yet the regime needs to realize too that most Jordanians are civilians under the age of 30 who believe that time is on their side. Ultimately, the regime's best strategy would be to realize that these challenges are in fact also opportunities, and to return to its place ahead of the wave of reform and change, or risk being swept away by it.

Middle East Report Online, July 13, 2010 (http://www.merip.org/mero/mero071310.html) (accessed on July 13, 2010). 